\title{
THE EFFECT OF LEADERSHIP ON EMPLOYEE LOYALTY AND ORGANIZATIONAL TRUST AS MEDIATION VARIABLES
}

\section{Untung La Paudi, I Ketut R Sudiarditha, Usep Suhud}

Master of Management Faculty of Economics, Jakarta State University

Email: untunglapaudi@gmail.com, ketut.sudiarditha@unj.ac.id, usepsuhud@ feunj.ac.id

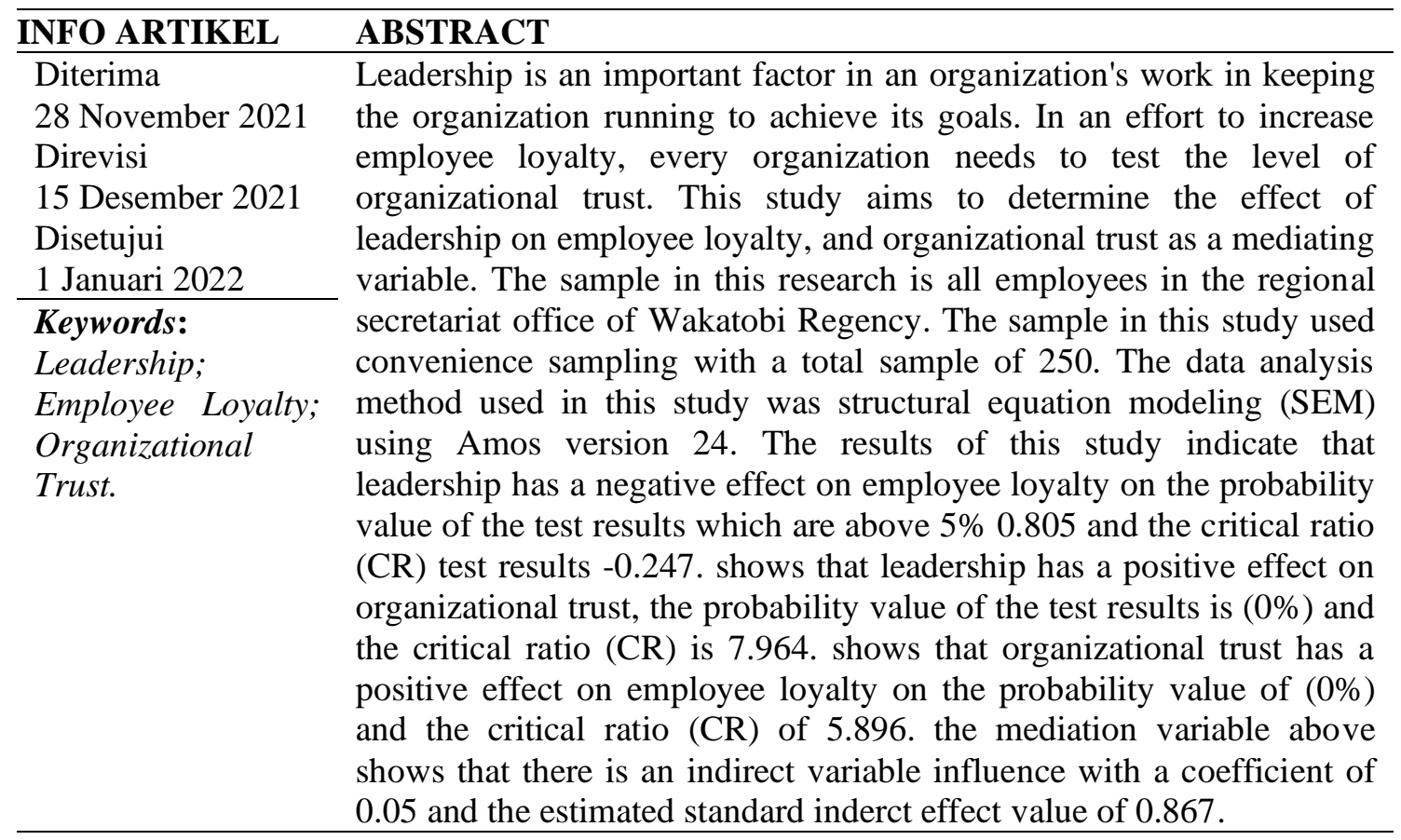

\section{Introduction}

The quality of the leader is often considered the most important factor in the success or failure of the organization (Hamzah et al., 2021). as well as the success or failure of an organization both business and public oriented, usually perceived as the success or failure of the leader. The role of the leader is so important that the issue of leadership has become a factor that has attracted the attention of researchers in the field of organizational behavior. When leaders demonstrate good leadership, employees will always have the opportunity to learn proper behavior when dealing with work. Likewise with the public bureaucracy (public service), the leader plays a very strategic role.

In public organizations, subordinates work always depend on the leader. If the leader does not have the ability to lead, then very complex tasks cannot be done properly. Leadership is defined as the ability to exert influence and motivate individuals to achieve organizational goals (Gibson et al., 2006). The ability to influence will determine the method used by employees in achieving work results. Another thing is based on the argument that a leader has the authority to plan, direct, coordinate, and monitor employee behavior.

Organizational leaders can influence behavior by creating organizational systems

$\begin{array}{ll}\text { How to cite: } & \text { Paudi, U. I., Sudiarditha, I. K. R, Usep Suhud, (2022). The Effect of Leadership on Employee } \\ & \text { Loyalty and Organizational Trust As Mediation Variables, Jurnal Syntax Transformation, 3(1). } \\ & \text { https://doi.org/10.46799/jst.v3i1.495 } \\ \text { E-ISSN: } & 2721-2769 \\ \text { Published by: } & \text { Ridwan Institute }\end{array}$


and processes that suit individual needs, group needs and organizational needs. Effective leadership is supported by trust and loyalty from high employees who will be smarter in making decisions. A leader with intelligent leadership is expected to be able to plan, guide, direct, give orders and control subordinates. Leadership has a direct positive effect on team performance and loyalty (Pujiastuti et al., 2020). Employees in dealing with uncertain working conditions and the role of leadership in making different decisions based on their respective mindsets lead to unfair fulfillment of employee expectations so as to trigger feelings of satisfaction or dissatisfaction.

In addition, a weak level of loyalty is characterized by non-objective behavior in making policies and irritability when faced with problems, thus indicating when working conditions are chronic. As a result, employees become uncooperative, do not respect each other so that it has a bad impact on employees, becomes disappointed and dissatisfied. It is proven by the nature of the employee who is unable to express and control his emotions so that it has a bad impact on himself and the organization.

One of the main problems in the organization is how the level of trust and loyalty of employees is increased to do a good job. How people can work together, follow orders both agree and disagree, obey superiors and so on in achieving organizational work goals.

Factors that influence the trust and loyalty of employees at the regional secretariat office in Wakatobi Regency are leadership and organizational trust and employee loyalty. Because it is very important to research, an organization will succeed or even fail largely determined by leadership. It is the leader who is responsible for the failure of the implementation of a job and this shows that in an organization the position of the leader is the most important position.

Leadership plays a dominant, crucial role in the overall effort to improve performance, both at the individual, group, and organizational levels. The results of the pre-survey (pre-study) that became the research problem in this study were the low level of organizational trust held by secretariat office employees. Wakatobi district area, thus affecting employee loyalty which is marked by the presence of employee work results that are not in accordance with the assessment elements, namely, Lack of achievement of targets given by the leadership to employees,quantity and timeliness in completing work so that the leader must give a warning to the employee in addition to the lack of employee initiative in completing the work so that any work that needs to be completed is always waiting for the leader's orders, this is very detrimental to the organization, the work will be completed when the leader is in the office but when the leader are not in the office then the work will not be completed.

One of the institutions or agencies that must continue to pay attention to employee loyalty is the Wakatobi Regency Regional Secretariat Office as the implementation of services in the public sector, of course, in creating something that develops, a good management system is needed both internally and externally, so that good cooperation is established, creating trust in the community. organization and high employee loyalty to the organization.

This is the hope of the regional secretariat office, but based on the observation, that the employees of the regional secretariat of the Wakatobi district have high loyalty to the agency, but in reality this is not the case, the employees who are judged to really work according to operational standards and fully serve the organization. Furthermore, based on the 
results of interviews with employees in the sub-section of staffing management, it is stated that there is still a breakdown in information in communication between leaders in this case the regional secretary and employees. This is evidenced by the change in new regulations among the internal organization which aims to discipline employees suddenly without any discussion of the employees involved in certain fields.

Regional activities that have never been presented transparently to employees so that performance activities are not optimally carried out by sub-divisions, there is a selection of honorary employee recruitment which is sometimes situational, in the sense of being closed and not publicly informed, although according to the head of the regional secretariat this This is done because of the need for manpower that must be addressed immediately. And there is no good reward system in the form of awards given to employees who excel or actively participate in organizational development.

Another complaint is the assignment of tasks that are sometimes not in accordance with the work of the employees in the sense of being delegated and the existence of a very short time limit in completing the task. This prevents employees from submitting assignments on time, and superiors do not want to hear any excuses from employees who are negligent in carrying out the assigned tasks. This causes the Wakatobi district secretariat office to always lose the loyalty of its employees due to a lack of employee trust in the organization and leadership values, even though the employee's service period in the agency is quite long and competent.

Facts found in the field, although some employees have worked according to procedures and provisions, there are still some employees who are not honest and responsible in carrying out their duties and functions and there are still many employees who often arrive late and there are still minimal achievements that are not in accordance with the target so that unsatisfied with achievement.

This condition gives rise toproblems for leaders to provide additional motivational encouragement or punishment to employees in order to be able to complete the work more optimally. Likewise, it is necessary to create a condition that can provide satisfaction for its employees. The lack of employee trust is the main problem in this study so that the role of leaders and employees together is needed to improve and evaluate each employee's work with the aim of further increasing trust and work loyalty. charged to him.

According to (Abadiyah, 2021), indicating that organizational trust has a partially mediating effect on the studied relationships. The relationship between leadership and organizational trust has the power to innovate behavior. In particular, the affective component of organizational trust influences the relationship leadership influence on the form of innovation.

Organizations that are able to succeed in achieving a goal and are able to fulfill their responsibilities are highly dependent on their managers (leaders). If the leader is able to carry out well, it is very likely that the organization will achieve its goals. These values can lead to the creation of public trust and organizational trust. Leaders who have honesty can inspire trust in others (Rezaei et al., 2012) and leadership have a direct positive effect on performance and loyalty (Pujiastuti et al., 2020).

according to (Manzoor, 2012), leadership is about getting one right way, whether it is for others to follow and trust. The creation of organizational trust in the organization is the responsibility of qualified managers and leaders. The role of managers and leaders in organizational reform is very important.

The process of creating deep organizational trust is the responsibility of 
qualified managers and leaders. The role of managers and leaders in organizational reform is very important (Bakiev, 2013) In terms of psychological state, (Keegan et al., 1991) defines trust as performing a risky act with the belief that everyone involved in the act will act competently and compliantly. Organizational trust refers to the belief of employees in the achievement of the goals of the company and of organizational leaders, and the belief that in the end, the actions of the organization will prove to be beneficial to the employees (Paliszkiewicz et al., 2014).

Therefore (Esmaeili, 2001) identify loyal employees as employees who show a high level of organizational loyalty in the organization in which they operate, have a strong belief in accepting the goals and values of the organization, are ready to make every effort possible to serve

Furthermore, leadership has shown that leadership styles such as empowerment, reward and team work have a positive impact on employee satisfaction, and employee satisfaction in turn promotes employee loyalty (Chang et al., 2010). that good leadership will provide space for employees or employees in giving appreciation in increasing the level of loyalty to leaders and organizations. In addition, it was indeed found that there was a positive and significant relationship between communication, openness to innovation, participation, trust in teamwork and organizational trust, trust in management, trust in coworkers, and trust in the workplace (Isik et al., 2015).

In research (I Made Artha Wibawa, Eka Afnan Troena, Armanu, Noermijati Lumpkin, 2014), concluded that human resources are important factors that mediate organizational culture and spiritual leadership in influencing employee loyalty, servant leadership is significantly positively correlated with employee loyalty (Ding et al., 2012). Personal characteristics have a significant effect on loyalty (Hardianty et al,
2014). It is stated that leadership can affect employee loyalty. In research (Pucetaite \& Novelskaite, 2014) showed that organizational trust had a partially mediating effect on the relationships studied.

Organizational trust and innovative behavior, but also moderate the indirect effect of employee and organizational relationships on innovative behavior through organizational trust. Employees will have a positive attitude and engage in behaviors that are beneficial to the organization, (Eisenbeiss et al., 2008). such as organizational trust, high loyalty to the organization, and more likely to do their jobs with greater effort (Torka et al., 2005), Employees with high levels of organizational trust will perform more reciprocal behavior for the organization (Parzefall, 2008) If the quality of employeeorganizational relationships is high, the organization is likely to provide employees with secure jobs and a variety of rewards.

\section{Method}

Reliability test is a measuring instrument, which shows the accuracy, consistency and determination of the measurement. Reliability testing is a process carried out to test data constraints. This is used as a reference in this reliability test is Cronbach's alpha from data analysis. Cronbach's alpha is an illustration of how big the correlation factor is between a variable and another variable (Sekaran \& Bougie, 2016).

This study tested the reliability using Cronbach's alpha. The reason is because Cronbach's alpha test is the most frequently used questionnaire reliability testing technique. The reference value of Cronbach's alpha is above 0.70 . That the lower limit for Cronbach's alpha is 0.70 . Cronbach's alpha is said to be good if it is more than 0.7 (Sun et al., 2019). Hypothesis testing. 
Table 1

Hypothesis testing

\begin{tabular}{cc}
\hline GOF Index & Cut of value \\
\hline Chi-square & Expected small \\
\hline Significant probability & 0.05 \\
\hline GFI & 0.90 \\
\hline AGFI & 0.90 \\
\hline CFI & 0.95 \\
\hline TLI/NNFI & 0.95 \\
\hline CMIN/DF & 2.00 \\
\hline RMSEA & 0.80 \\
\hline
\end{tabular}

After evaluating the overall model as well as assessing the oodness of fit and it was found that the tested model was not fit, it was treated as a modification or model resp. Modification of the model in the AMOS program can be done by looking at the output of the Modification index. As a note, MI output on AMOS requires the data to be free of missing values.

\section{Result dan Discussion}

1. First Hypothesis (H1): Leadership has a negative effect on employee loyalty.

Leadership has a negative effect on employee loyalty in alpha (0.05) and the Critical ration value of 1.98 . This can be seen from the probability value of the test results which are above 5\% 0.805 and the critical ratio (CR) of the test results which are below 1.98 , which is -0.247 . Which means, there is a negative influence of Leadership on Employee Loyalty.

In this study, it can be seen that leaders treat employees differently, leaders do not supervise the work done by employees, leaders do not provide complete information to employees and leaders do not provide rewards or awards achieved by employees, proving that in this study there were negative numbers after In the research test, there were negative numbers which contradicted the question of leadership indicators.

So this affects the behavior of employees with several indicator questions that have been tested where employees always come not according to a predetermined time, where employees do not maintain the image of the organization, lack of good performance, employees tend to see the side of personal interests rather than the interests of the organization, and employees do not adhere to the values applied by the organization. In the indicator of employee loyalty, it can be said that the test of this research with the relationship between the two leadership variables on the organization, it can be seen in table 4.19 that the information rejected proves that there is something that the organization must pay attention to in terms of leadership factors which will have a negative impact on employee loyalty.

This is not in accordance with the theory put forward by he found that leadership skills to intensely communicate and engage employees in their daily work play an important role in gaining loyalty (e Cunha, 2002) These results are not in line with the research results. According to the research (Liden et al., 2008) showed that another aspect of servant leadership, helping subordinates grow and succeed, had a positive impact on increasing employee loyalty. Next According to research (Ding et al., 2012) leadership affects employee loyalty. Leadership has a direct positive effect on team performance and loyalty (Pujiastuti 
et al., 2020). According to research (Wellyanto, SC, \& Halim, 2017) shows that the transformational leadership style has a positive and significant effect on employee loyalty. So in this study that leadership has a negative effect on employee loyalty and the hypothesis is rejected.

2. The second hypothesis (H2): Leadership has a positive effect on organizational trust

Based on Table 4.16 shows that leadership has a positive effect on organizational trust in alpha (0.05) and the critical ratio value is 1.98 . This can be seen from the probability value of the test results which are below $5 \%$, namely $(0 \%)$ and the critical ratio (CR) of the test results which are above 1.98 , which is 7.964. Which means, there is a positive and significant influence of leadership on organizational trust.

This result is in accordance with the theory put forward by (Hamzah et al., 2021) Leadership has characteristics that are interesting to the process of building trust, that in leadership indicators that leaders can be fair. As a facilitator, and being respectful can affect the level of trust in the organization, this is an important part so that the goals in the organization can be achieved as organizational goals. In this case the leader has a big role to be able to increase employee confidence in the organization (Rahayuningsih, 2019).

It can be seen that the relationship between the two variables of leadership and organizational trust can have a positive impact when leadership can be fair, that leadership does not discriminate between employees from one another in providing organizational tasks, the leader as a catalyst that the leader always supervises the work to be done by the employees. employees and leaders can provide complete information about the correct implementation of work instructions. Appreciation, leaders are able to give awards in the form of praise to their employees for the work done, this has a positive impact on leadership.

In the dimension of caring organizational trust, that employees have a level of concern for the organization, employees are willing to help their coworkers. Openness, that employees have integrity. Identification, that employees can be able to see the problems that exist in the organization. Communication, that employees have good communication between leaders and fellow employees in the organization, in communication employees have a level of openness to fellow employees in the organization. As well as a sense of justice, that what has been done by employees is in accordance with the salary or benefits they receive from the organization.

In research (Çoğaltay \& Karadağ, 2015) in research that leadership affects organizational trust. Furthermore, According to (Rezaei et al., 2012) stated that leadership has a positive effect on organizational trust. Leadership effectiveness has a direct positive effect on organizational trust (Pranitasari, 2020). Further in his research (Rua \& Araújo, 2016) Thus it can be concluded that leadership has a positive effect on organizational trust.

3. Third hypothesis (H3): Organizational trust has a positive effect on employee loyalty

Based on Table 4.16 shows that organizational trust has a positive effect on employee loyalty at alpha (0.05) and the critical ratio value of 1.98 . This can be seen from the probability value of the test results which are below 5\%, namely $(0 \%)$ and the critical ratio (CR) of the test results which are above 1.98 , which is 
5.896. Which means, there is a positive and significant influence of organizational trust on employee loyalty.

This is in accordance with the theory According to (Esmaeili, 2001) that the process of creating job loyalty within the company is associated with a strong urge to remain a member of the organization, the desire to try as much as possible for the organization.

Furthermore, research by (Matzler \& Renzl, 2006) shows that trust in colleagues and trust in management are strong predictors of employee satisfaction, and employee satisfaction, in turn, affects employee loyalty and it is known that trust in the organization will increase employee loyalty. In this study, organizational trust has a positive effect on employee loyalty (Al-Shalabi, 2019) The results showed that all forms of the relationship studied influenced organizational loyalty. Organizational identification and organizational trust affect organizational loyalty jointly or independently (Isik et al., 2015). Next in research (Matzler \& Renzl, 2006) showed that trust in colleagues and trust in management were strong predictors of employee satisfaction,

4. Fourth hypothesis (H4): Leadership and Employee Loyalty have a positive effect through Organizational Trust as a Mediation Variable.

The results of the mediation variable test above, it shows that there is an indirect variable effect with a coefficient of 0.05 and the estimated standard inderct effect value of 0.867 means that there is a positive influence between leadership on employee loyalty indirectly and significantly and trust organization as a mediating variable.

According to Steers and Porter (1983), employee loyalty is the extent to which an employee identifies with his/her workplace which is indicated by the desire to work and try his best and the process by which an employee makes a definite decision not to leave the company if he does not make extreme mistakes.

In research shows that organizational trust as a partial mediating effect. According to Bettencourt et al (Pucetaite \& Novelskaite, 2014) in (Luthans, 2021), explained that employee loyalty is the behavior of members in an organization that reflects loyalty to the organization through promotions and always maintains the image of the company outside the company.

In this research there is a positive influence between leadership and employee loyalty and organizational trust as a mediating variable. In the leadership indicators, there are several variable indicators that serve as a reference for the influence of leadership on employee loyalty. It is fair, where the leader does not discriminate between one employee and another, here we see that there is no difference made by the leader to the employee. As a catalyst, where the leader will always supervise the work done by his employees, the leader is able to provide the correct direction of information to his employees. Being appreciative, the leader gives praise or appreciation to his employees for the achievement of good work results.

Next, look at indicators of organizational trust, which have a positive effect, namely the level of concern, employees have a level of concern for employees, employees are ready to help other employees in the form of organizational work. Openness, employees have integrity and honesty. Identification, employees are able to see the problems that occur in the organization. Communication, employees 
have good communication with leaders and among employees. Fairness, employees believe that the salary and benefits they receive from the organization are in accordance with what they provide to the organization.

Next, look to see indicators that have a positive effect on employee loyalty variables. Obeying the organization's regulations, employees always adhere to the working hours set by the organization. Service, that employees will maintain a good image from things that can harm the organization, employees provide good performance to the organization, dedication to the organization, employees place themselves by looking at the interests of the organization to meet what the organization expects. Internalization of organizational values, where employees always adhere to the values that have been implemented by the organization properly.

Organizational trust and innovative behavior, but also moderate the indirect effect of employee-organization relationship on innovative behavior through organizational trust ( $\mathrm{Yu}$ et al., 2018). Furthermore, in the same study conducted by (Isik et al., 2015) There is a positive and significant relationship between communication, openness to innovation, participation, trust in team work and organizational trust, trust in management, trust in colleagues, and trust in the workplace. And in the following research conducted by In research (Pucetaite \& Novelskaite, 2014) shows that organizational trust has a partial mediating effect. The overall results show that the relationship between leadership and employee loyalty and organizational trust as a mediating variable has a relationship between these variables.

\section{Conclusion}

Based on the results of the research, discussion, and analysis that have been carried out in the previous chapter, it can be concluded that what can be drawn from research on the factors of leadership, employee loyalty, and organizational trust

The first hypothesis, testing leadership has a negative effect on employee loyalty, where the results have a negative influence on leadership on employee loyalty, these results indicate that when leadership is low, employee loyalty is lower.

The second hypothesis, examines leadership on organizational trust where the results of the study show that there is a positive influence between leadership on organizational trust. This shows that increased organizational trust will be able to increase employee loyalty.

The third hypothesis, examines organizational trust on employee loyalty, where the results of the study show that there is a positive and significant influence between organizational trust and employee loyalty. This shows that increased organizational trust will increase employee loyalty

The fourth hypothesis, testing leadership has a positive effect on employee loyalty and organizational trust as a mediating variable, where the results of the study show that there is a positive and significant influence between leadership on employee loyalty and organizational trust as a mediating variable, this shows that leadership and organizational trust increase, will can increase employee loyalty.

\section{BIBLIOGRAFI}

Abadiyah, A. K. (2021). Pengaruh Gaya Kepemimpinan Terhadap Kepuasan Kerja Karyawan pada PT Columbia Cabang Palu. Jurnal Sinar Manajemen, 8(1), 7-13.Google Scholar 
Al-Shalabi，F. S. (2019). The relationship between organisational trust and organisational identification and its effect on organisational loyalty. Int. J. Economics and Business Research, 18(1). Google Scholar

Bakiev, E. (2013). The influence of interpersonal trust and organizational commitment on perceived organizational performance. Journal of Applied Economics and Business Research, 3(3), 166-180. Google Scholar

Chang, C. C., Chiu, C. M., \& Chen, C. A. (2010). The effect of TQM practices on employee satisfaction and loyalty in government. Total Quality Management, 21(12), 1299-1314. Google Scholar

Çoğaltay, N., \& Karadağ, E. (2015). Introduction to meta-analysis. In Leadership and organizational outcomes (pp. 19-28). Springer. Google Scholar

Ding, D., Lu, H., Song, Y., \& Lu, Q. (2012). Relationship of servant leadership and employee loyalty: The mediating role of employee satisfaction. IBusiness, 4(03), 208. Google Scholar

e Cunha, M. P. (2002). "The Best Place to Be" Managing Control and Employee Loyalty in a Knowledge-Intensive Company. The Journal of Applied Behavioral Science, 38(4), 481-495. Google Scholar

Eisenbeiss, S. A., Van Knippenberg, D., \& Boerner, S. (2008). Transformational leadership and team innovation: integrating team climate principles. Journal of Applied Psychology, 93(6), 1438. Google Scholar

Esmaeili, K. (2001). Organizational commitment. Journal of Tadbir, 112, 66-69. Google Scholar

Gibson, M. C., Patel, A. B., Nagpal, R., \&
Perrimon, N. (2006). The emergence of geometric order in proliferating metazoan epithelia. Nature, 442(7106), 1038-1041. Google Scholar

Hamzah, N. H., Nasir, M. K. M., \& Wahab, J. A. (2021). The Effects of Principals' Digital Leadership on Teachers' Digital Teaching during the COVID-19 Pandemic in Malaysia. Journal of Education and E-Learning Research, 8(2), 216-221. Google Scholar

I Made Artha Wibawa, Eka Afnan Troena, Armanu, Noermijati Lumpkin, A. (2014). The Role of Organizational Culture on Spiritual Leadership, Human Capital, and Employee Loyalty. Journal of Business and Management, volume 6(6).

Isik, M., Timuroglu, K., \& Aliyev, Y. (2015). The Relationship between Teamwork and Organizational Trust: Relations Between Cognitive, Affective and Action Loyalty. International Journal of Research in Business and Social Science (2147-4478), 4(1), 113-132. Google Scholar

Keegan, K., Johnson, D. E., Williams, L. T., \& Hayman, M. J. (1991). Isolation of an additional member of the fibroblast growth factor receptor family, FGFR-3. Proceedings of the National Academy of Sciences, 88(4), 1095-1099. Google Scholar

Liden, R., Wayne, S., Zhao, H., \& Henderson, D. (2008). Multi-level approaches to leadership. The Leadership Quarterly, 19(2), 161-177. Google Scholar

Luthans, F. (2021). Organizational Behavior _ An Evidence-Based Approach. Google Scholar

Manzoor, Q.-A. (2012). Impact of employees motivation on organizational effectiveness. Business Management and Strategy, 3(1), 1-12. Google Scholar 
Matzler, K., \& Renzl, B. (2006). The relationship between interpersonal trust, employee satisfaction, and employee loyalty. Total Quality Management and Business Excellence, 17(10), 12611271. Google Scholar

Paliszkiewicz, J., Koohang, A., Gołuchowski, J., \& Horn Nord, J. (2014). Management trust, organizational trust, and organizational performance: advancing and measuring a theoretical model. Management and Production Engineering Review, 5. Google Scholar

Parzefall, M.-R. (2008). Psychological contracts and reciprocity: A study in a Finnish context. The International Journal of Human Resource Management, 19(9), 1703-1719. Google Scholar

Pranitasari, D. (2020). The Influence Of Effective Leadership And Organizational Trust To Teacher's Work Motivation And Organizational CommitmenT (S3). Google Scholar

Pucetaite, R., \& Novelskaite, A. (2014). The mediating effect of organizational trust in the relationship between leader member exchange and organizational innovativeness. Economics and Management, 19(2), 192-201. Google Scholar

Pujiastuti, E. T., Budiarti, H. N., Sulaeman, K. A., Faturachman, D., \& Setiawati, R. (2020). Influence of Leadership, Loyalty, and Followership on Team Performance of PT Gaharu Galangan International. International Journal of Marine Engineering Innovation and Research, 5(2). Google Scholar

Rahayuningsih, I. (2019). The Positive Impact Of Organizational Trust: A Systematic Review. Journal of Educational, Health and Community
Psychology, 8(1). Google Scholar

Rezaei, M., Salehi, S., Shafiei, M., \& Sabet, S. (2012). Servant Leadership And Organizational Trust: The Mediating Effect Of The Leader Trust And Organizational Communication, Emerging Markets Journal. Volume. Google Scholar

Rua, O. D. L., \& Araújo, J. M. C. (2016). Relacionando liderazgo transformacional y confianza organizacional:i Tiene el compromiso organizacional un efecto mediador? Cuad. Gest, 16(1), 43-62. Google Scholar

Sekaran, U., \& Bougie, R. (2016). Research methods for business: A skill building approach. John Wiley \& Sons. Google Scholar

Sun, L., Ji, S., \& Ye, J. (2019). Multi-label dimensionality reduction. Chapman and Hall/CRC. Google Scholar

Torka, N., Looise, J. K., \& van Riemsdijk, M. (2005). Commitment and the new employment relationship. Exploring a forgotten perspective: Employers commitment. Management Revue, 525539. Google Scholar

Wellyanto, SC, \& Halim, G. (2017). Analysis of the Effect of Leadership Style on Employee Loyalty at Hotel X Bali. Journal of Hospitality and Service Management, 5(2).

Yu, M.-C., Mai, Q., Tsai, S.-B., \& Dai, Y. (2018). An empirical study on the organizational trust, employeeorganization relationship and innovative behavior from the integrated perspective of social exchange and organizational sustainability. Sustainability, 10(3), 864. Google Scholar 
The Effect of Leadership on Employee Loyalty and Organizational Trust As Mediation

\section{Copyright holder :}

Untung La Paudi, I Ketut R Sudiarditha, Usep Suhud (2022)

First publication right :

Jurnal Syntax Transformation

This article is licensed under:

(c) $\underset{\mathrm{EY}}{\mathrm{B}} \mathrm{SA}$ 